\title{
The Right to Land: To Whom Belongs after a Reconciliation Law in Egypt
}

Professor Dr. Ahmed M. Soliman (D) P SC

Architectural Department, Faculty of Engineering, Alexandria University, Egypt

E-mail: ahmsoliman@yahoo.com, ahmsoliman@alexu.edu.eg

\begin{tabular}{l} 
ARTICLE INFO: \\
\hline Article History: \\
Received: 25 October 2021 \\
Revised: 15 January 2022 \\
Accepted: 28 January 2022 \\
Available online: 14 February \\
2022 \\
\hline
\end{tabular}

Keywords:

Reconciliation Law;

Housing;

Property;

Regulations;

Building Violations;

Land Management;

Egypt.

This article is an open-access article

distributed under the terms and conditions

of the Creative Commons Attribution 4.0 International (CC BY 4.0)

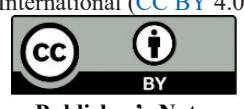

Publisher's Note:

Journal of Contemporary Urban Affairs stays neutral with regard to jurisdictional claims in published maps and institutional affiliations.

\section{ABSTRACT}

A revolutionary book by De Soto to formalize land tenure by changing "dead capital" to "life capital" has become the trademark in Egypt of issuing a temporary reconciliation law of 2019 and its amendment to approve a legal certificate to the violators against a certain fee. The question is does this law legalize informal housing? Is it enough to introduce a legal certificate to secure land tenure for the violators? How would this law apply on the ground? Depending on the deductive methodology, this paper traces sociotechnical transitions concerning legalizing the status quo of building/land, tenure security, real-estate markets (formal/informal) caused by laws on buildings violations reconciliation. The idea is to take a step back and look at a wide angle of the problem in the future to arrive at a clear picture of the influences of the introduction of a new law on the land market, before making a decision. The paper assumes that the temporary reconciliation law in Egypt is opening the debate on the alteration of land management to govern the status quo of the chaos of the right to land. It concludes this temporary reconciliation law has created a state of decayed/wealth, social inclusion/exclusion of the bottom of the social pyramid nevertheless to whom the justification is affected.

JOURNAL OF CONTEMPORARY URBAN AFFAIRS (2022), 6(2), 96-111. https://doi.org/10.25034/ijcua.2022.v6n2-1

$$
\text { Copyright (๑) } 2022 \text { by Professor Dr. Ahmed M. Soliman. }
$$

\section{Introduction}

Land is the main component of urban development, and it is also the source of individual and communal identity, the basis for shelter, and it is considered as financing for transitoriented development (Home, 2020; Suzuki et al., 2015). It displays and measures the level of improvements and the degree of the quality of the built environment subsequently, determining the level of both poverty reduction and the quality of urban infrastructure. Therefore, urban expansion, infrastructure development, and resilience of cities have to be controlled by a proper land management system. Rapid population growth combined with informal spatial growth and the spreading of the shadow economy in Egypt has created a chaos-built

*Corresponding Author:

Architectural Department, Faculty of Engineering,

Alexandria University, Egypt

Email address: ahmsoliman@yahoo.com ,

ahmsoliman@alexu.edu.eg 
environment. This has resulted in an annual housing production of 263,838 units during 19962006, of these, 55.6 percent were formal and the rest informal (Soliman, 2012a). It is estimated that 14.58 million housing units were out of the real estate market during 2016 in urban areas in Egypt, of which 6.40 million units were vacant and 8.18 million units were closed. On the other hand, a figure of 42 percent of the housing stock in the Greater Cairo Region is seized under rent control (CAPMAS, 2021). De Soto (2003) indicated in the year 2000 the cost of informal housing construction in Egypt amounted to US\$241.4 billion. This housing crucible in Egypt has encouraged spontaneous housing development by which it became and will continue to be the main feature of the Egyptian landscape (Sims, 2011; Soliman, 2021).

Securing land and property rights in Egypt exists through informal means and became the preferred and affordable method for people who are most in need of housing plots. But there is evidence that the variations of security of land tenure mechanisms are poorly designed in which about 60-80 percent of violators do not benefit from the introduction of the reconciliation law (Soliman, 2021). The right to land became the main problem that faces low-income groups and the pressing need to secure women's property rights (Archambault \& Zoomers, 2015; De Soto, 2003; Home, 2020; McAuslan, 2013; Payne et al., 2009). It constitutes not only for using it to construct a shelter but also as a commodity and an asset to secure their economic future from a rapid inflation process.

The main objective of the study is to arrive at a practical and legal framework to legalize and formalize informal housing, and it aims to explore the influence of applying the reconciliation law on legalizing and formalizing informal housing. The goal is to investigate the procedures of the law on the sociotechnical tendency and how are implemented on the ground (see Figure 1). The objective, aim, and goal of the paper is primarily exploratory. It combines qualitative and quantitative methods to reflect the prevailing situation, therefore, questions the instruments of the temporary reconciliation law and who would be benefited. Thus, this research enquiries the implementation of the law on the ground, and its influence on the real estate market. Conversely, the aim and objective of the study are looking to measure or analyze the effect of the introduction of the reconciliation law in simplifying land registration and legalization processes to prevent the threat of evictions or demolition. Thus, the research is likely to be quantitative, and considers quantitative data collection methods (e.g., evaluating the outcomes of issuing a new law) and analyses (e.g., statistical analysis). As illustrated in Figure (1) the research methodology is a retrospect and prospect in nature to arrive at a precise picture before a decision is taken. Thus, the research is exploratory and at the same time confirmatory in nature.

The paper highlights the assumption that the planning regulations of building and land violations of the urban agglomerations in Egypt have a disciplinary trend and cannot be separated from a set of urban planning and land management policies. It assumes the reservation of urban land management at national and local levels is the cornerstone for land supply. Also, the paper assumes the discussion on the legalization of land tenure and the formalization of the status quo of the hosing informality have to be linked by previous land reforms, land regulations, and legal-political processes that produce informal land market. Therefore, the construction challenge was one of the Egyptian most complicated issues, due to the multiplicity of laws and the interlacing of responsible authorities. The Unified Building Law No 119 of 2008 (UBL2008) came to bypass the complexities of Law 106 of 1976 to regulate construction work, Law 78 of 1974 for electric elevators, and previous planning laws. The UBL2008 regulated previous interrelation between owner and tenant of Law No. 49 of 1977 and Law No. 136 of 1981 on renting and selling premises. The gaps that appeared with the application of the UBL2008 caused an increase in problems instead of solving them, hence the state insisted on the urgent need for issuing the Buildings Violations Temporary Reconciliation Law number 17 of 2019 (BVTRL2019).

The paper here is an important contribution to poverty alleviation strategies by examining the above two assumptions through four arguments. First is the scarcity of a suitable land tenure results from the absence of land governance and management. It is due to the failure of planning and legal frameworks to afford an appropriate environment for the real estate market. Second is the preservation of the processes and mechanisms of the status quo of the informality in remodelling the prevailing legal policies to meet the Goal 11 of the SDGs of 2015. Third, land 
formalization schemes have to convey other profit, for people most in need, either in kind or in cash or both to people's life. Finally, proper legal instruments and land governances are the components of the implementation of legal land rights. The findings of the study have been widely dispersed. The study concludes that reconciliation law options to formalize the building's violations and regulate land tenure are passing through complicated processes by which the final output has not afforded a concrete solution to tackle informality but sustains the status quo of the informality. The law does not provide an answer to register or secure land tenure as a concrete model to the right to land for the most in need of the population. The present work, therefore, approaches the question of reconciliation of building and land violations mainly based on the pressure between, on the one hand, the state's regulations and, on the other hand, the internal mechanisms or specific dynamics of land tenure, land registration, and ownership in the spontaneous development.

The paper constitutes of five parts: first, general background for the informal arrangements of access to land in Egypt; second, a theoretical debate on building violations; third, a discussion of the role of laws in shaping gentrification, fifth, a discussion on building reconciliation; and finally, the paper demands a future study for future actions.

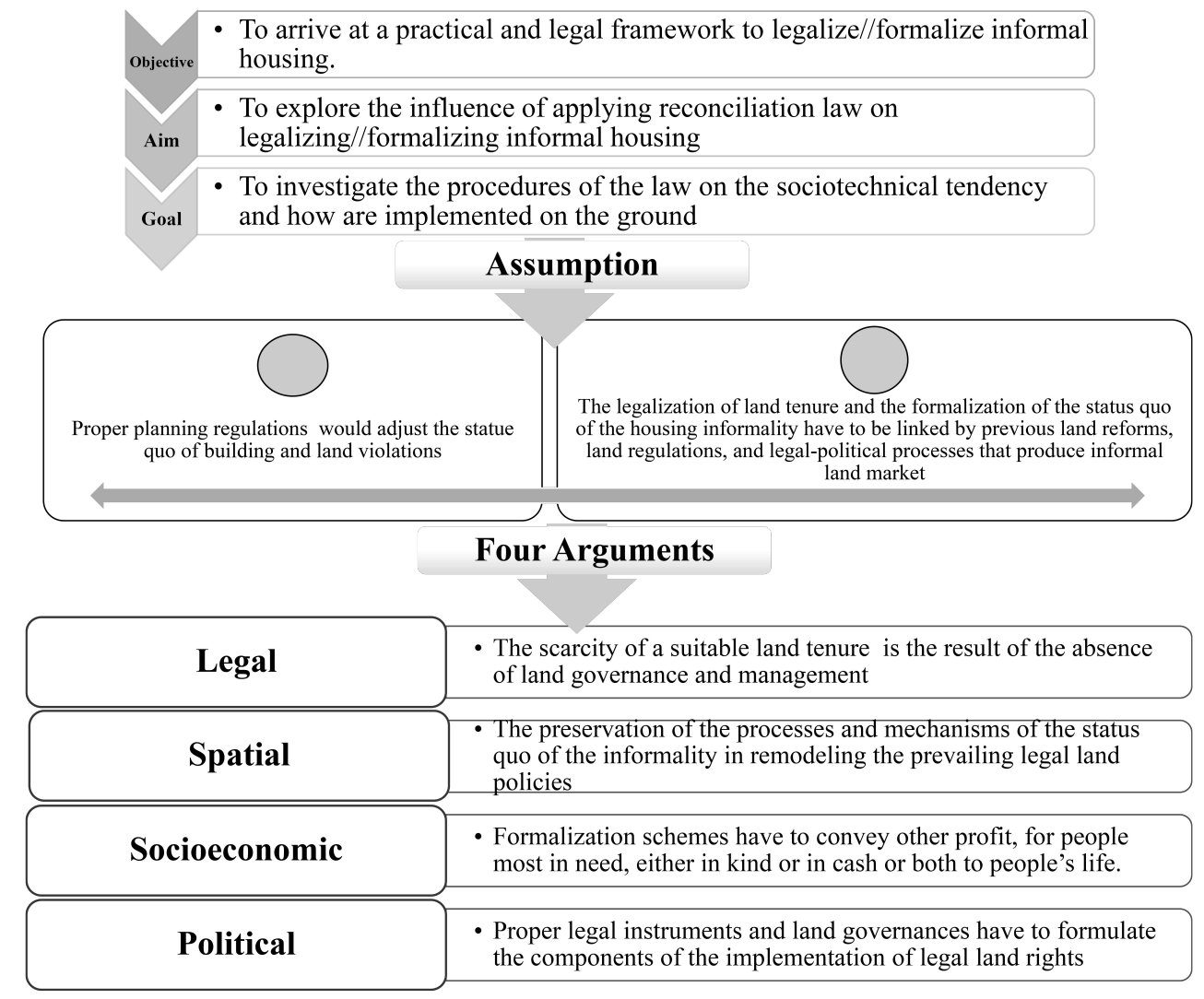

Figure 1. Illustrates the deductive methodology which is used to explore and confirm the current situation to arrive at a precise picture before a decision is taken.

\section{Illegal Arrangements of Access to Land}

Most of the successes of the urban poor in gaining access to land in the recent past have been through semi-legal or illegal means. The entrepreneur involved in these processes has had to resort to innovative strategies to overcome the specific legal and economic constraints in any given context. Land acquisition and the mechanisms of acquiring land have differed markedly between countries. In some countries, the poor invade or squat land, elsewhere the purchase of land from private property developers. Both cases are well represented in Egypt, where the former occurs in squatting areas, while the other in the semi-informal housing sector (Soliman, 2004). A third phenomenon is taken place in the Muslim's countries, which is renting public land 
for a specific period (Heker) with paying a symbol rent for the government bodies. Such land often lacks planning permission from the local authorities, or it is outside the city boundary or suited on agricultural land. In some places, the poor or the international organization rent from the private landlords or from public departments to house refugees (as in Beirut and Amman). Furthermore, people might occupy land illegally sharing the luxuries of the upper-class residential suburbs. Variations of this nature have not only been observed between nations, but also within each country and between cities. For example, in Egypt as an Islamic country-, rented public land (Wqaf or Heker) can be found in the big cities, and religious urban centers (Such as Tanta city) or surrounding the old core of the Egyptian cities.

The form of land acquisition differs from one country to another. There are many ways of acquiring land within urban areas by individuals or a group of low-income, or squatters. The most important is the organized squatter acquisition by relatively large groups (Lipton, 2009), a phenomenon most found in Latin America. The second is the unorganized acquisition by individual households or small groups of people (Payne et al., 2009), which occurs widely throughout the Global South. The third is private formal acquisition and/or speculation of agricultural land which later subdivided illegally by private developers or small landlords and sold in the market as residential uses plots (Soliman, 2004). Finally, there is semi-organized acquisition through a co-operation or partnerships between the official bodies and/or the squatters and lowincome groups. These processes depend upon the mechanisms of land acquisition and are linked with the transitions of socioeconomic, political transitions, and the level of technology that society is passing through (for example see (Kanger \& Schot, 2019; Piketty, 2014).

The success and failure of land acquisition or the right to land depend on several variables. Among these are the type of tenure status, the size of people who occupy land, the willingness of landlords to sell or purchase land, and the willingness of the state backing land invasion (McAuslan, 2013). It must be emphasized that the socio-economic, political, and urban transitions reasons, all play a salient part in such acquisition. Some land acquisition occurs during election time, and others during the political crisis, and in some countries during the introduction of new socio-economic regulation of a given environment, for example, Egypt (Soliman, 2021). Also, due to the way that the state acts towards the housing policy as laissezfair policy, which accelerates land acquisition within urban areas.

The actual land acquisition and erection processes vary according to the political and physical conditions in the city concerned, as well as the level of availability of urban land expansion. However, most acquisitions are neither well-coordinated nor financially viable, and the immediate objective is simply to settle quickly into the chosen area to obtain de facto possession by a display of group solidarity or to settle through the incremental process to obtain de-jure recognition. Most of these processes have relied on the informal economy and informal land markets (DurandLasserve \& Selod, 2009). There are numerous detailed studies of this observed in different Egyptian cities, and within each city in Egypt. It is of particular significance because such differences occur within and between a certain city. Why are acquisitions of land permitted in some locations and not in others? How has the distribution of land use and its value within a city affected such acquisitions? Do the mechanisms of land acquisition differ within a given area? If so, why do they differ, and what are the reasons for these variations? Does the land market within a city affect land acquisition and regularization within a given setting? How do the different forms of land regularization relate to the socio-economic, political, and urban growth characteristics of a city, and what is the effect of these aspects at the national and local level? How far, to what extent, why, and when has the government been involved or participated in such acquisition or regularization?

A lack of control of low-income land acquisition is general in most of the Egyptian cities because the factor of greatest importance to low-income groups desperate for homes is land availability. The most significant kind of available illegal land, however, is that which has a very low value, or the leeway of conversion of agricultural land to other uses and/or in bad environmental conditions for local authorities, affluent groups, and private developers. Thus, middle and low- 
income groups acquire land which less profitable for the private developers, and not with the interest of the local authorities. This location usually is located either on the periphery of the city or near job opportunities, or at least connected to reasonable transport facilities, as well as, far behind the eyes of both affluent groups and the local authorities. The image of low-income locations is that they are usually sited on riverbanks, unused land, steep slopes, deteriorated agricultural land, hillsides, railway, and road rights of way. Illegal subdivided agricultural areas on peri-urban areas are affordable methods to acquire housing plots. The middleman is playing a great role to conduct informal land supply in cooperation with land speculators. This land is usually unsuitably located for residential development, or has topographical difficulties, or is badly serviced, or has low value, or includes the most polluted and worst areas in the city, or as derelict desert areas, and finally, it is usually located in a badly socialenvironmental condition. While high and middle and above middle-income groups occupy the healthy locations in the city, the nastiest is left to shelter the poor. Briefly, the degree of residential and land-use segregation is likely to be very great within the Egyptian cities. The mechanisms of land supply for the urban poor are quite specific in different Egyptian cities and are tended to change over time, reflecting in both economic and political terms and the commodity nature of urban land. It is argued that substantial efforts through appropriate land legalization programs would enhance the security of land tenure for the poor, subsequently, would reduce the poverty level (Home, 2020; Lipton, 2009).

Because urban low-income groups acquire land illegally, tenure statues are generally in doubt and insecure, and since the insecurity of tenure and the fear of eviction are serious obstacles preventing house improvements in low-income settlements. Tenure security in past years became a natural means for removing these obstacles (Durand-Lasserve, 2005; Payne et al., 2009), improving economic status, and alleviating poverty (De Soto, 2003). It is argued that not only the security of tenure has a direct effect on housing improvements, but also other factors are relevant(Gilbert, 2012). It may be true that the urban poor has common interests in the legal land title, but what type of land title is needed? Is it legal recognition in law (de jure) or legal recognition in practice (de facto), or is it an intermediate tenure (customary tenure or hybridize tenure)? How could the land title be provided for informal residential areassquatting and semi-informal- and what form of the title? What are the consequences of land legislation on the housing market within informal areas and areas surrounding them? Who will benefit from such legislation? Will land legislation speed the housing process or will it make for a further reduction in the housing stock? Should the urban poor be excluded from occupying better land, or should they be integrated into the urban context? Little has been done to answer these questions and to address the relationships between the socioeconomic, political, and urban growth characteristics within a city, the right to land, the land delivery system, and the action of the government towards these changes is essential.

Recently, the state of Egypt introduces a new law to legalize the status quo of informality and to eliminate the spreading of arbitrary urban growth. However, the Egyptian government issued a Building Violations Temporary Reconciliation Law No. 17 of 2019 (BVTRL2019) (Gazette, 2019), and its amendment in 2020 (ABVTRL2020) was imposed from July to September 2020. The aim is to establish a legal treaty between violators and the local authority to legalize the status quo. A down payment of $25 \%$ of the cost of building violations has to be paid in advance to the local authority to obtain the legal resolutions. The plenty would reach around 2.7 billion USA $\$$ to cover 2.0 million violators. However, Gilbert (2012) showed that neither legal land title nor its application would not offer a luckily better situation. Therefore, the following part analyses the consequences of the reconciliation law and the degree of its gentrification. A new typology of informality has performed the Egyptian landscape; however, the following part examines these consequences.

\section{Building Violations}

There are huge academic debates on the way that the formulation of housing informality has been affected by the socioeconomic, political, and spatial transitions in Egypt (Doherty, 2010; Dorman, 2013; Guerzoni, 2009; Sims, 2011; Soliman, 2021) in which the 
taxonomies of informality are quizzed (Khalifa, 2011 ; Soliman, 2004). The amelioration of the housing crisis in Egypt over time has been frustrated by which urban sprawl has dominated the Egyptian built environment (Denis, 2012; Soliman, 2012b; Soliman, 2021). This research is not intended to retrospect the Egyptian housing situation, instead, it focuses on the state's efforts to legalize or formalize the housing illegality and how, whom, when, why, and who would legalize it. After the two revolts of 2011 and 2013, Egypt observed a great loss of 150,000-200,000 Feddan' of agricultural land to illicit development (Soliman, 2021).

Not only does the state of chaos resulting from the two revolutions weaken the state, but also is the absence of applying planning control in the last three decades. Inappropriate land governance has led to unable the state to deal with building and land violations. Thus, the spreading of urban informality has dominated the landscape of Egyptian cities. More than $50 \%$ of the built-up areas have been characterized by illegality (Soliman, 2021). After the June 30 revolution, the search for solutions began, but it required intensive studies of the real estate market. Statistical figures and indicators confirm that the provision of housing alternatives before dealing with violations and infringements is huge. The annual population growth rate is $2.4 \%$, while the number of populations has increased by about 20 million since 2010. This growth puts pressure on the inhabited area, agricultural lands, services, and facilities. It is estimated that Egypt is receiving a new birth per sixteen seconds and is expecting the total population will reach 180 million persons by 2050 (CAPMAS, 2021).

Looking at the bill of violations, the problem becomes miserable, as the size of the violating buildings has reached 3 million units and 240 000 real estates (CAPMAS, 2021). Informal areas spread in 226 of 234 cities, and agricultural land encroachments amounted to 1.9 million cases, and it needed to compensate for the pressure on the infrastructure to more than 86 billion pounds for drainage and drinking water projects. The matter is not an exchange of accusations and responsibilities. The responsibility is collective and shared among the state and the society. In addition to the long legacy of mismanagement of land supply since the fifties, our practices as individuals were not far from the problem. For example, it is estimated that about 14.58 million uninhabited housing units (CAPMAS, 2021), and while their owners close them without justification, no others find a suitable home. At present, most areas are no longer able to absorb more arbitrary housing production. In addition, the violations are eating the agricultural land and affecting food security. According to the Prime Minister's statements (Shawkat, 2021), city violations amounted to $50 \%$ of the size of buildings, and the percentage has risen to $70 \%$ of new construction since 2015. The alternatives are uncomfortable to provide better opportunities for life and work. The urban space must be expanded and distributed the population density over more areas instead of narrowing the currently inhabited percentage of Egypt, which does not exceed $7 \%$, in which the state is planning to reach $12 \%$. Will this happen? Or it is a dream in the desert (Sims, 2015).

Aerial photography is recorded to permit the state the monitor of the urban and spatial map and to determine the size of the urban sprawl. It is also verifying the expansions of the real estate and the areas of intersections as spaces suitable for construction. Cases not recorded in this photography are considered a violation, and the conditions of reconciliation for their construction outside the city's boundary do not apply. Aerial photography data related to construction on agricultural lands or in places close to residential blocks and approved urban space lines are mapped. The violations of building without a license or violating the conditions of the license, height restrictions, and the nature of use within the urban space are detected. All these areas are covered by reconciliation until April 8, 2019, which is the date of approval of the Building Violations Temporary Reconciliation Law No. 17 of 2019 (BVTRL2019). Thus, the BVTRL2019 came as a continuation of the fourth generation of the construction boom of 18 new cities, resettlements of unsafe areas and social housing, and the addition of 160,000 Feddans to the urban space. The state is forced to act due to the pressures resulting from violations and infringements, as the utility bill has jumped several times and the cost of delivering sewage

${ }^{1}$ One Feddan equals 0.42 hectare 
to villages has reached more than 200 billion pounds due to this random expansion. The same is true in the capitals of governorates and new cities, as the building violations are putting pressure on roads and networks of facilities and services. These have affected the standard of living of citizens, so the BVTRL2019 came to control the urban informality and improve living conditions.

The restrictions of the Unified Building Law, no 119 of 2008 (UBL2008) and the two revolts in Egypt have led to the increase of violations. According to official figures, the number has reached 2800000 violating buildings, with a total of 396000 floors, comprising about 40 million units. For example, Cairo and Giza alone have about 209000 buildings violated. There are no conclusive detailed figures, but according to the estimates of the official authorities (CAPMAS, 2021), most of the violations pertain to licenses for real estate, shops, garages, change of activity, fences, etc. The high percentage of fees, fines, and the proceeds so far are from companies, investors, or capable citizens who have multiple or extensive violations in area and value. As illustrated in figure 2 building violations vary according to the nature of the abuse by the property owner, but the most prominent of them are building without a license, violating the terms of the license while not affecting construction safety. Changing the use from residential to commercial or otherwise, noncompliance with the applicable planning requirements, and violating drawings is dominated violations. Architectural and construction, heightening the roles of violation. To the point that building on agricultural land and changing its use from agricultural use to other uses, especially building housing units on them without a building permit, represents most building violations. Most of these cases may be reconciled unless they affect the safety of the property or violate the regulations of aviation laws and others.

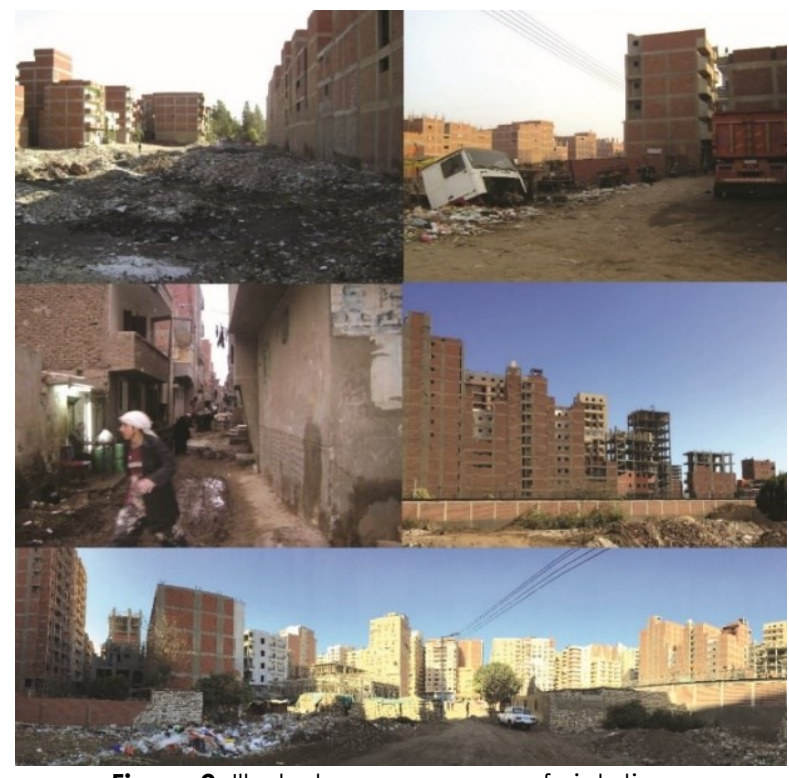

Figure 2. Illustrates some cases of violations.

Reconciliation is prohibited in the following seven violations. Buildings that are defective in the safety of construction, Encroachment on the perpendicular organization lines and the official approved easement lines, Violations of buildings and facilities with distinctive architectural style, Exceeding the height restrictions established by the Civil Aviation Authority or exceeding the requirements of State Defense Affairs, Building on state-owned land, unless the person concerned has submitted an application to legalize his status in accordance with the law, Building on lands subject to the Antiquities Protection and Nile River Protection Law, and finally, Changing the uses of areas for which detailed plans approved by the administrative authority have been issued. The latter is also including buildings outside the urban space except for the exceptions mentioned in the UBL2008. Surface violations that fall under the category of violating the conditions of licenses are as follow. Changing the licensed property whose license includes the purpose of its construction and the purpose assigned to it. The purpose of changing the use is to transform the building or any of its units for a purpose other than the licensed purpose before obtaining the necessary approval from the competent authority is considered illegal. In this case, it is not permissible to reconcile areas with approved detailed plans. Violations of using garages fall within the scope of change of use, and if it is in an area for which approved 
regulatory plans have been issued, it can be reconciled with the approval of the administration. Following the applicable regulatory procedures, and considering the estimates of the technical committees, the price per meter and the value of the land has to be estimated.

In general, the BVTRL2019 does not provide the possibility of reconciliation over crossing the lines of urban space. It sets several exceptions to this matter. The most important of which are projects and activities that serve the areas of agricultural and animal products within the framework of the government's plan and based on a proposal from the Minister of Agriculture. Also, it allows to build on agricultural lands on a private residence or establish a service building, near the estates of cities and villages and their dependencies. These completed buildings are inhabited by residents and enjoying facilities if they are on lands that have lost the elements of agriculture and according to the data of the last aerial photography. The state introduces several regulations to frustrate the spreading of urban informality on peri-urban areas and alleviate the pressure and conflict over the right to land. Subsequently, the simplification of the procedures and increasing the motivations are issued to encourage putting unused housing units for rent (UN-Habitat, 2021). The BVTRL2019 separates at this point between two matters, the first is the encroachment on state property, and the second is a violation of building without a license or outside the legal and building requirements. A reconciliation with these cases can be made to lead to the legalization of land. This would require a decision to accept the reconciliation before submitting proof of reconciling the situation according to Article 89 of the executive regulations of the BVTRL2019.

Urban expansion does not stop. Replanning the urban space in the old areas, launching several social housing projects, and implementing new cities in all governorates, are all in progress. According to official figures, the state added 480,000 Feddan to the urban space between 2008-2018 to accommodate 24 million people with a density of 50 per Feddan. The truth is that the problem is not related to the narrowness of the urban space or the scarcity of land, but rather it is the culture and practices of the society. For example, the construction areas in the villages witness price speculation. Instead of a citizen is selling a plot of agricultural land to buy a suitable location for construction, the citizen decides to build his house on his land out of jealousy from his neighbour or a refusal to take advantage of the price.

\section{The role of laws in shaping gentrification}

Shaping gentrification has been organized by the public authority through various forms. This is done by imposing new regulations to guide, support, promote, and steer how gentrification develops in specific urban contexts. Consequently, the modalities of 'gentrification' in Egypt are determined by laws and regulations. The state of Egypt issued a Buildings Violation Temporary Reconciliation Law No. 17 of 2019 (BVTRL2019) to eliminate and prevent the chaos of the building and to regulate urbanization processes. The objectives of the BVTRL2019 are to reconcile violations of the UBL2008 and codify the conditions of previous violations, to control the construction conditions in Egypt, reorganize the urban map, and work to develop the system of facilities and services. The BVTRL2019 aims to:

- $\quad$ Correct the error, legalize the situation, and provide resources to address the problems of pressure on facilities.

- Issue a safety certificate or a birth certificate for each property or reconciled that will serve as a national number for the property to give it a legal status

- Achieve a stable, civilized urban appearance, and achieve the citizens' interest in owning an organized and fully serviced society.

- $\quad$ Represent an advanced step towards saving millions of buildings from the sword of the UBL2008, which provided for the removal or confiscation of the unit. On the contrary, the law does not aim at demolishing real estate.

- Open the door to reconciliation and legalization of the situation and does not include procedures regarding confiscation or imprisonment for violators.

- Limit the demolition of buildings to lands of aggression against public facilities, roads and railways, or encroachment on state property and lands of river dumping.

- $\quad$ Avoid any property on land owned by personal property that falls within the 
BVTRL2019 and does not face the risk of removal.

The law has been introduced to tackle spatial chaos, control arbitrary situations, and regulate the real estate sector. So far, not a single case of removal of an inhabited property has been carried out, even inland encroachments and usurpation of state property. But most of these types of violations are unused, and they are constructions of an investment nature carried out by their owners to place possessions, seize the site, and profit from resale or use in other activities, not for personal accommodation. Building violations built on squatters' lands have not been excluded from the executive regulations of the law (Gazette, 2019). Squatting and encroachments on state lands are two separate violations. This requires submitting a request for reconciliation and then legalizing the status of the land itself with its subsidiary.

After meeting these requirements, the violator will enjoy the opportunity to conciliate and will give the property a legal form. The opposite is true for public land where buildings on state property involve two violations, first, require legalization of laying the land and then reconciling the building later. The law regulates the issue of reconciliation by granting the right to each owner or occupant of a unit to apply to reconcile the violations prescribed in it. It means that no requirements to apply for reconciliation for all the roles or the property's unit, but if there is no attempt by some individuals to restrain the state or obstruct dealing with roles. The law did not specify the identity of who must apply for reconciliation. It leaves the opportunity for all those who wish to reconcile. According to the text of the third article of the executive regulations of the law, each stakeholder, whether owner, occupant, or union of occupants, has the right to apply for reconciliation. This requires providing a request for confirmation of its capacity and its connection to the property. The text of the second article of the law indicated that the technical committee would decide on the applications. This committee is headed by a consulting engineer specializing in structural engineering, with the membership of two engineers. One of whom is civil engineering, and the other is architecture, provided that the experience of each of them is not less than five years, in addition to a representative of the
Ministry of Interior from the Civil Protection Department.

\subsection{The submission mechanisms to reconciliation}

With the implementation of the BVTRL2019, some problems emerged. The Amendments to the Temporary Reconciliation Law issued No. 1 of 2020 (ATRL2020) (Gazette, 2020) came to facilitate the citizens' procedures, and the report of an ordinary engineer was satisfied. Regarding the submission mechanisms, required documents and payment systems are all simplified. The exaggeration of the consultancy offices has simplified and put in force for the safety report's fees, and the exclusion of the previous violations of the UBL2008. The government did not specify the mechanisms for completing the reconciliation documents. The matter came within the texts of the BVTRL2019. The law stipulated that a construction safety report be attached to the property from a consultancy office. With the difficulty of this matter and the exaggeration of offices, Parliament moved to mitigate it by the ATRL2020. The issue is that stipulating the certificate be through Ordinary Union Engineer. without requiring the approval of a consultancy office or the approval of the Engineers Syndicate.

The Prime Minister announced procedural solutions to apply for reconciliation with the least number of papers, to obtain Form 3 to secure the legal status of the property, and stop any measures taken against it (Shawkat, 2021). An additional period has been given to complete the papers and the rest of the reconciliation procedures. As illustrated in figure 3 the processes of the submission mechanisms to reconciliation are composed of three stages: initial stage, intermediate stage, and finally final stage. The first stage composes the required documents and details information of violation. The order begins by applying to the neighbourhood or the device to which the property belongs with the least number of documents. The completion of the papers is required within a certain period, including the engineering file, and payment of the examination fee. The second stage requires the completion of the down payment of the fees to pass the documents to the specific committee for the final inspection. If initially accepted, the seriousness of the 
reconciliation is paid. The value of the fine can be paid in cash or 3 annual instalments without interest and a down payment of $25 \%$. The final stage passes through filtrations of the documents and evaluates the final fees. Form 3 is issued which is considered as a certificate to be used for the installation of services.

All governorates have taken executive measures to facilitate citizens, most notably increasing the number of progress outlets and technology service centres, cancelling workers' leave, extending work until nine in the evening. The responsible bodies are preparing a weekly report on the progress, and forming committees headed by deputy governors to follow up on the file, in addition to discussion seminars and guidance and awareness activities in each region. Form 3 is a certificate obtained by the person wishing to reconcile under the text of Article 3 of the BVTRL2019. It includes the citizen's data and the property and its area and represents an acknowledgement from the local unit or the administrative authority to start the reconciliation procedures for violations. After finishing the inspection of the property and the evaluation processes of the documents submitted by the citizen, the date of committing the violation, and paying the required fees, the license in the form of a certificate is issued. This certificate serves as confirmation from the administrative authority to accept the reconciliation request procedurally and to take the legal and administrative path to present it to the competent committee. This form allows the immediate cessation of all lawsuits related to the violation in court, and the suspension of the implementation of judgments, decisions, and procedures issued regarding the violation until the settlement request is decided.

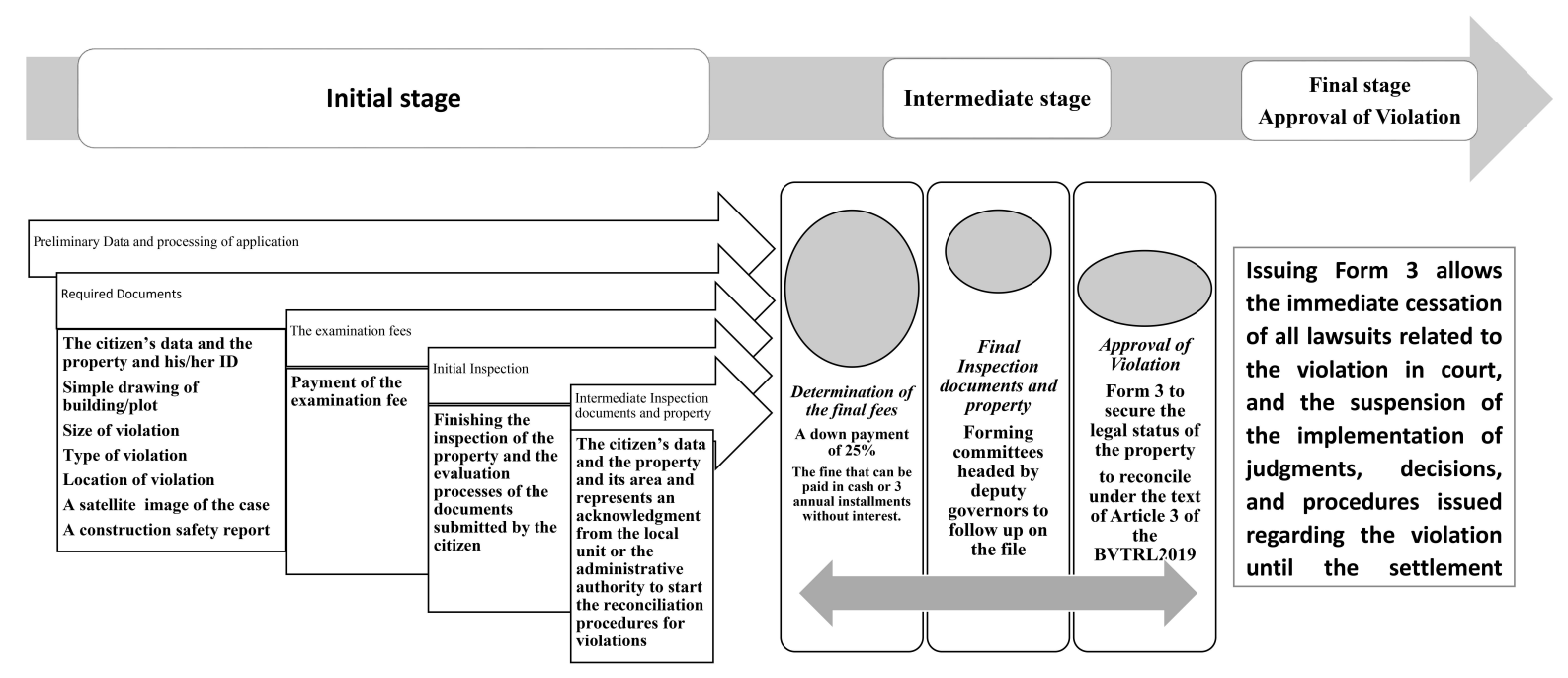

Figure 3. The processes of the submission mechanisms to reconciliation.

Each property or reconciled unit will obtain a safety certificate or a birth certificate. It serves as a national number for the property that gives it a legal status and a sound existence so that the owner can register it in the Property Proclamation Department (PPD), and deal with it by selling, and formally delivering facilities and services. Accordingly, it increases the value of the property and increases safety and stability rates for its inhabitants. The time course of reconciliation is not related to the government. It is related to the legal text that specified 6 months from the date of issuing the executive regulations of the BVTRL2019, which expired at the end of January 2020, and with the issuance of ATRL2020 and then its executive regulations in March, the period was renewed until the end of September 2020. The date of a final submission is a legal deadline that cannot be exceeded.

\subsection{The value of fees}

The law defines the mechanism for forming the committee concerned with determining the value of the reconciliation. The committee includes two representatives of the competent administrative authority, two specialists in real estate appraisal with their approval by the 
Financial Supervisory Authority, and a representative of the Ministry of Finance. The law does not leave the matter at all and stipulates considering geographical and urban considerations, the level of the region, and the extent to enjoying the facilities and services. Because the law does not aim at levying, but rather to correct the error, legalize the situation and provide resources to address the problems of pressure on the facilities. The law has set the value of the fine. It is started from 50 pounds and up to 2000 pounds per square meter as a maximum. It means that a unit of 100 square meters will not exceed the value of the reconciliation over 5000 EGP in the villages and 200,000 EGP in the most luxurious and luxurious areas. The government announced many facilities during the recent period. The deadline was extended for completing papers for an additional two months and further for six months to be ended in September 2020. The Prime Minister announced that re-examination of prices, assessment of fines, accepting applications with the fewest documents are acceptable. The most important deceleration is granting applicants Form 3 to stop all legal procedures immediately against violators. The law sets percentages of fines according to the type of violation. Table 1 illustrates the estimated value of the meter price in the area. The values of fees were reduced, and the fine was allowed on a credit basis over 3 years. All violators were allowed for all real estate to benefit from the reconciliation.

Table 1. The estimated value of fines of the meter price in the area.

\begin{tabular}{|c|c|c|}
\hline Type of violation & $\begin{array}{c}\text { Fines } \% \text { of the } \\
\text { value of square } \\
\text { meter }\end{array}$ & Comments \\
\hline $\begin{array}{c}\text { Building with a license while exceeding the requirements of } \\
\text { planning or changing use }\end{array}$ & 100 & \multirow{8}{*}{$\begin{array}{l}\text { The main problem is how } \\
\text { would calculate or assess } \\
\text { the price of the square } \\
\text { meter of each area. Also, } \\
\text { who will assess the property } \\
\text { value, what are the criteria } \\
\text { used in the assessment. }\end{array}$} \\
\hline $\begin{array}{l}\text { Building without a license while conforming to the requirements } \\
\text { of planning }\end{array}$ & 100 & \\
\hline $\begin{array}{l}\text { Violating the architectural and construction drawings of the } \\
\text { license }\end{array}$ & 50 & \\
\hline $\begin{array}{l}\text { Violating the architectural and construction drawings of the } \\
\text { license }\end{array}$ & 25 & \\
\hline Violating the number of floors and heights & 25 & \\
\hline $\begin{array}{l}\text { Violating the construction drawings and matching the } \\
\text { architectural drawings, the flat and the number of floors }\end{array}$ & 25 & \\
\hline $\begin{array}{l}\text { Violating the architectural drawings and matching the } \\
\text { construction drawings and violating the number of floors }\end{array}$ & 20 & \\
\hline $\begin{array}{l}\text { Violating the architectural drawings while matching the } \\
\text { construction drawings and the number of floors }\end{array}$ & 5 & \\
\hline
\end{tabular}

Source: (Gazette, 2019)

The seriousness of reconciliation is limited to $25 \%$ of the total value of a square meter of the unit/land, with a maximum of fees of 5,000 and 20,000 EPG for villages and cities in violation respectively. A reduction of $10 \%$ and $40 \%$ for violation for villages and cities respectively in violation of responses authorized buildings lines. Further reductions of $12 \%$ and $50 \%$ for villages and cities respectively are given in increasing the surface area of rooms. Also, a reduction of $20 \%$ and $80 \%$ for villages and cities in violations of building the entire roof, and $40 \%$ and $16 \%$ for villages and cities in violations of building without obtaining a license. The value of the penalty is 250 thousand EPG for provincial capitals and 30 thousand EPG for villages and 120 thousand EPG for cities in converting the basement into an unlicensed activity. Indeed, the governorates reduced the reconciliation rates between 10 and $55 \%$, according to some regions. Cairo, for example, set a $20 \%$ reduction in the eastern region, $20 \%$ in Suez, Dakahlia and Menoufia, 25\% in Minya, Alexandria, Ismailia, Sharqia, Aswan, Matrouh, South Sinai, $30 \%$ in Luxor and Port Said, $35 \%$ in Fayoum, $40 \%$ in Kafr El-Sheikh, Sohag, the Red Sea, and finally $50 \%$ in New Valley and Damietta.

The law provides for the payment of a fee for examining the application submitted regarding the violating property or unit. These fees start from 125 EGP and 500 EGP for villages and cities respectively. A maximum of 5,000 EGP according to the geographical area, size of the unit/plot, market value, and type of violation. Reconciliation is not a levy law as 
some claim, with evidence that it set a low minimum price per square meter, and a maximum that cannot be exceeded, regardless of the nature of the area. The idea of financial fines is to enhance spending on services and facilities in areas of unplanned sprawl after the violations caused pressure on utility networks to the extent that it needs more projects and expansions. The proceeds of the reconciliation will not go to finance the sections of the general budget or the annual deficit in it. Rather, it will be transferred to a special account in the public treasury for collection and redistribution, provided that the proceeds of each governorate are spent within the same governorate. This fund will be used to develop facilities and services and strengthen infrastructure, including 25\% for the Social Housing and Development Fund, $39 \%$ for infrastructure, water, and wastewater.

\subsection{Law enforcement period}

The amendments to the BVTRL2019 allowed extending the period of law enforcement, controlling administrative procedures, and evaluation mechanisms to ensure that the value of the violation is not exaggerated. It also forces the administration authorities to receive all requests, provided that the decision on them is a matter of the competent committees only. In addition to dealing with violations according to their types, nature, and value of areas market, the law is considering the social dimension and fair application of controls and requirements.

The technical committees formed for this purpose issue their decisions regarding the request for reconciliation. Reports are submitted to the governors or heads of the bodies with jurisdiction, and the decision to accept or reject the reconciliation request is within four months from the date of submitting the request. According to Article 4, the applicant has the right to complete the documents later after the closing date, with the applicant's right to appeal if the request is rejected (Gazette, 2020). The technical committees, governorate authorities, and city agencies are responsible for issuing estimated price lists according to regions, urban and civilization level, and availability of services. While the calculation is according to indicative percentages according to the type of violation, which ranges between 5 and $100 \%$ of the square meter value if this is not less than 50
EGP and not more than 5000 EGP per square meter in all cases.

The amendments to the law made it possible to pay the value in three annual instalments. The applicant who is wishing to reconcile pays $25 \%$ of the value as a conciliation within 60 days of the committee's approval of the request. Bearing in mind that if any instalment is delayed or two consecutive instalments are not paid during the three years the settlement decision shall be cancelled. In all cases, a final decision shall not be issued to reconcile until after the full amount has been paid. According to the text of the law, the owner of the violated unit/land or the person wishing to reconcile must pay the consideration for reconciliation and legalization of the situation. Alternatively, the owner has to apply for instalments, accompanied by evidence of payment of the advance payment within 60 days of the committee's approval, and then paint the existing and unfinished facades of the building. As stated in the text of the law, the effects produced by the reconciliation are to legalize the status of the property and give it a legal entity and the possibility of enjoying the facilities and services in an official way. The law stipulates that accepting the reconciliation does not result in any violation of property rights, and the issuance of the committee's decision and the completion of the reconciliation. Payment procedures are considered a license that produces all the effects of licenses for violating works. The law specifies 60 days from the date of the committee's approval of the request to pay the value of the reconciliation, or the advance payment and the instalment request. and decisions issued regarding real estate.

According to the advantages provided by the BVTRL2019 on some building violations, once the application is submitted, all decisions or actions taken against the property are frozen. Form 3 indicates the unpaid fines, and the fines previously paid will be calculated within the total value of the reconciliation. In the absence of an owner of the property, the occupiers' union, or the owner of any unit in the property, can apply for reconciliation with proof of its relationship to the unit. This path can be disabled through the RL2019, once the application is submitted and Form 3 is obtained. All legal procedures and lawsuits against the property are stopped, and even the provisions in effect are suspended even if 
they imprison the violator. Upon acceptance of the reconciliation and the compellation of procedures, the violator is released. According to Article 10 of the law, a person whose application is rejected, or a high fine is imposed on him may file a complaint within 30 days from the date applicant was notified of the decision. Decide on the grievance within 90 days, and the expiry of the period without a decision is considered as acceptance of the grievance.

The BVTRL2019 regulates the legal process regarding the violating real estate and its owners. Legislatively, the mandate will return to the UBL2008, and in implementation, the state authorities have moved to put in place effective mechanisms to prevent infringements and building violations. In turn, the Ministry of Housing has established a central unit to follow up on violations of new cities. It is continuous periodic monitoring, preparing a database of licenses, and monitoring compliance with violations. It also addresses and eliminates violations in the bud, granting broader powers to security directors and city agencies. By legalizing the conditions of the violating real estate and buildings, the population density in each area can be accurately counted, the utility networks re-planned. The needs of each city or village are determined, and investments are made to spend on the water, sewage, electricity, and other projects. These improvements provide better services and reduce pressure on the family's resources that go to purchase needs that compensate for the absence of amenities, and thus the eminence of life will improve the standard of living.

Recently, the Egyptian Cabinet (Shawkat, 2021) approved two draft laws amending some provisions of the Real Estate Registration Law No. 114 of 1946, and the Income Tax Law promulgated by Law No. 91 of 2005. The amendments to the provisions of the Real Estate Registration Law aim to facilitate the procedures for registering property, through three steps. The first is separating tax payment from registration procedures and fees. Second is the possibility of registration despite the absence of a sequence of registered property in several cases. These are; if the registration applicant has a valid document, 5 years of possession and good faith, and the presence of a final judgment of ownership or other real rights in kind. The third is the seizure of possession for a period of more than 15 years with the intention of ownership with the realization of the interest of the real estate registry. These amendments will open new disputes among the landowners and might lead to the defragmentation of land ownership in Egypt. Also, these amendments do not touch the reconsolidation law nor are setting up clear steps for land registration.

\section{Conclusions}

What is happening in recent years is serious accountability of the localities, by increasing oversight, controlling procedures, and embargoing corruption through administrative control and amendments to the UBL2008 and the liberalization of the licensing system. It has been inherited for many years and the perpetrators are no longer serving or legally moving against them, and many of them have passed away. Although the state is moving at all levels, on the one hand, it is working to legalize the conditions of violations to control informal urbanization and increase the value of real estate wealth and facilitate its circulation by buying and selling on the other hand. A serious stand with erection on peri-urban areas to stop the bleeding of crop production and reach food security for 100 million citizens, is a matter of survival. The state does not evade its responsibility and has recognized that part of the problem is caused by mismanagement and corruption of localities over the past decades. The arbitrary gentrification should stop looking for solutions, especially since most villages and regions have become overcrowded and unable to support their residents and provide housing and job opportunities suitable for them.

The problems were the complexity, overlap, and overlapping of the authorities responsible for construction, and in addition to neglecting the approach of reconciliation and legalizing the situation. Also, there is no clear-cut policy for formalizing land status or at least finding a simple way for land registration, hence the right to land went into chaos. The BVTRL2019 sets difficult conditions that caused the spread of slums and illegal construction and entrusted the technical inspection body with the task of monitoring and follow-up to all the parties concerned with planning and organizing. Because of the limitations of the apparatus, the law became powerless. Moreover, the new amendments of the BVTRL2019 included simplifying the procedures and applying the 
one-stop system. It defines tasks and responsibilities for licensing, tightening control, and follow-up during construction operations, ensuring that works matched licenses. It also is considering the social dimension and geographical nature. None of the persons concerned with the law or those concerned with the file of building violations or encroachment on state lands and planning lines were interested in questioning, research, or aspiration for knowledge. Also, the governorates and localities were not interested in the explanation and clarification of the law. Thus came the state of shock and surprise with the start of the application. From this point, the law was reviewed in all its details, the construction conditions in the past and the laws regulating them, the extent of the risks that threatened Egypt.

The law applies to all real estate violates since 2008 , and the amendment issued No. 1 of 2020 was intended to open the door to previous violations of the UBL2008. But these applied only to those who are addressed by the law have a registered violation or a lawsuit regarding the violation, or they received communications from neighbourhoods and authorities concerned with the violation. The law applies to violating cases in cities and areas planned according to urban estates and planning lines that are subject to reconciliation. As for real estate built in villages before this date, it is not covered by the law, because before the issuance of the UBL2008, it was not required to obtain a building permit in villages and rural areas. But the law has contradicted as stated that all violations within the UBL2008 are under the umbrella of the BVTRL2019. While the Reconciliation Law includes all violations until the date of the last aerial photography on July 22, 2017, including unlicensed or violating residential buildings, shops, and change of use, with the possibility of reconciliation on buildings that infringe on the regulation lines or state property in case of agreement and legalization of the situation with the authority in charge.

The TRL2019, and its ATRL2020, and its executive regulations No. 1631 of 2019, and its amendments of the executive regulations No 800 and 936 of the year 2020 issued by Prime Minister Dr. Mustafa Madbouly, has passed through obstacles during its application on the ground. The law has opened intense controversy and uninterrupted questions. In this regard, and the fact that the crisis was not in the TRL2019, nor in the amendments, nor the executive articles, but rather the lack of interest in the law on the part of public opinion, and the lack of explanation of its articles and dialogue on them. The law caused a state of confusion and anxiety with its entry into force. It represents an important positive opportunity to prevent the deterioration of real estate, raises the value of buildings and units owned by citizens, and lays stable foundations to correct inherited errors and start planning for the future in a more conscious and disciplined manner. As we are approaching the beginning of 2022, there is not a single certificate has issued for violators, except for collecting the required fees of 40 billion EG. The question is why the state issued the TLR2019, what the main benefits are gained by the violators, has this law prevented or at least eliminate the spreading of the urban informality? Has this law opened a window to adjust the right to land or allow registering land/unit? Till now no single violator has formalized their land status nor legalized their unit.

Even though the law should issue a safety certificate or a birth certificate as a national number for the property, till now none has been issued. While it does not specify how this certificate gives a legal status to the violator. Also, this certificate does not meet the right to land nor represents a legal land transaction or does not valid to be presented to the Property Proclamation Department. The land ownership does not reflect in the building license rather the latter allows for the legal construction process. Therefore, the legalization of a piece of land is still vague and not legalized. The law might open a new dispute between the actual landowner and the housing property. Also, the certificate does not represent a legal document as collateral in front of the commercial banks to apply for a loan. In general, the law might provide a sort of legalization document for the housing units but does not legalize the tenure status of the land. In other words, legalization of the status of real estate does not give it a legal existence and the ability to trade, and to be a financial asset that can be invested, partnered in, and borrowed with its guarantee, rather it exhaustive the provision of financial of the violators. In short, the law does not provide security of land tenure, or an official document to be used to formalize real estate status nor authorize the informality. Rather the law has 
introduced a new status of official recognition in the form of "hybridization recognition". This recognition does not present a legal document in the Property Proclamation Department to officially register the land. It could be said that the law has gone away the right to land with the wind, nor provides a complete legal status for the violators, but open new disputes and conflicts between the violators and the state. Also, this law created or decayed wealth, social inclusion/exclusion, and increased/decreased the wealth of the bottom strata of the society. Last, it is hoped that this study is opening a new debate in the research arena to question the right to land and further in-depth research is required to understand these issues in the Global South.

\section{Acknowledgements}

The author wishes to acknowledge the editor and reviewers in the Journal of Contemporary Urban Affairs for their constructive feedback during the review process.

\section{Funding}

This research did not receive any specific grant from funding agencies in the public, commercial, or not-for-profit sectors.

\section{Conflicts of interest}

The Author(s) declare(s) that there is no conflict of interest.

\section{Data availability statement}

The original contributions presented in the study are included in the article/supplementary material, further inquiries can be directed to the corresponding author/s.

\section{Ethics statements}

Studies involving animal subjects: No animal studies are presented in this manuscript.

Studies involving human subjects: No human studies are presented in this manuscript.

Inclusion of identifiable human data: No potentially identifiable human images or data is presented in this study.

\section{CRediT authorship contribution statement}

Ahmed M. Soliman: Conceptualization, Data curation, Formal Analysis, Investigation, Methodology, Resources, Software Supervision, Validation, Visualization, Writing - original draft, Writing - review \& editing.

\section{References}

Archambault, C. S., \& Zoomers, A. (Eds.). (2015). Global Trends in Land Tenure Reform: Gender Impacts. London: Routledge. https://doi.org/10.4324/9781315765822

CAPMAS. (2021). General Statistics for Population and Housing: Population Census. Cairo, Egypt.: Central Agency for Public Mobilization and Statistics. https://www.capmas.gov.eg/Pages/Publications.aspx?pa ge_id $=5104 \&$ Year $=23562$

De Soto, H. (2003). The Mystery of Capital: Why Capitalism Triumphs in the West and Fails Everywhere Else. London: Black Swan.

Denis, E. (2012). The Commodification of the Ashwayyiat (s): Urban Land Market Unification and De Soto's Interventions in Egypt. Popular Housing and Urban Land Tenure in the Middle East, 227-258. https://doi.org/10.5743/cairo/9789774165405.003.0010

Doherty, G. (2010). Diane Singerman and Paul Amar, eds., Cairo Cosmopolitan: Politics, Culture and Urban Space in the New Globalized Middle East (Cairo: American University in Cairo Press, 2006). Pp. 564. \$39.50 cloth, $\$ 29.95$ paper. International Journal of Middle East Studies, 42(4), 725-726. https:/doi.org/10.1017/S0020743810001133

Dorman, W. J. (2013). Exclusion and Informality: The Praetorian Politics of Land Management in Cairo, Egypt. International Journal of Urban and Regional Research, 37(5), 1584-1610. https://doi.org/10.1111/j.14682427.2012.01202.x

Durand-Lasserve, A. (2005). Land for housing the poor in African cities: Are neo-customary processes an effective alternative to formal systems?'. Urban futures: Economic development and poverty reduction, 160-174. https://doi.org/10.3362/9781780446325.012

Durand-Lasserve, A., \& Selod, H. (2009). The formalization of urban land tenure in developing countries. In Urban land markets (pp. 101-132). Germany: Springer. https://doi.org/10.1007/978-1-40208862-9_5

Gazette, O. (2019). Building Violations Temporary Reconciliation Law (in Arabic). Gazette, Official, volume 14 Duplicate G, 8th April. http://admin.mhuc.gov.eg//Dynamic_Page/6369905087 48531932.pdf

Gazette, O. (2020). Amendments of Temporary Reconciliation Law (in Arabic). Official Gazette, 1(1), 26, Duplicate D, 7th January. Retrieved from: 
http://admin.mhuc.gov.eg//Dynamic_Page/6372920332 12837096.pdf

Gilbert, A. (2012). De Soto's The Mystery of Capital: reflections on the book's public impact. International development planning review, 34(3), $\mathrm{V}$. https://doi.org/10.3828/idpr.2012.15

Guerzoni, E. (2009). Cairo's Informal Areas Between Urban Challenges and Hidden Potentials. Portugal: Norprint SA.

Home, R. (2020). Land Issues for Urban Governance in Sub-Saharan Africa. Switzerland: Springer International Publishing. https://doi.org/10.1007/978-3-030-52504-0

Kanger, L., \& Schot, J. (2019). Deep transitions: Theorizing the long-term patterns of socio-technical change. Environmental Innovation and Societal Transitions, 32, 7-21. https://doi.org/10.1016/j.eist.2018.07.006

Khalifa, M. A. (2011). Redefining slums in Egypt: Unplanned versus unsafe areas. Habitat International, $35(1)$, https://doi.org/10.1016/j.habitatint.2010.03.004 40-49.

Lipton, M. (2009). Land reform in developing countries: property rights and property wrongs. London: Routledge. https://doi.org/10.4324/9780203876251

McAuslan, P. (2013). Land Law Reform in Eastern Africa: Traditional or Transformative?: A critical review of 50 years of land law reform in Eastern Africa 1961 - 2011. UK: Routledge. https://doi.org/10.4324/9780203491867

Payne, G., Durand-Lasserve, A., \& Rakodi, C. (2009). Social and Economic Impacts of Land Titling Programs in Urban and Periurban Areas: A Short Review of the Literature. In Urban Land Markets Improving Land Management for Successful Urbanization (pp. 133-161). London: Springer. https://doi.org/10.1007/978-1-40208862-9_6

Piketty, T. (2014). Capital in the Twenty-First Century. London: The Belknap Press of Harvard University Press. https://doi.org/10.4159/9780674369542
Shawkat, Y. (2021) Law Versus Optimization Development Brief (in Arabic), The built Environment Observatory. Retrieved from: https://marsadomran.info/policy_analysis/2021/0 $7 / 2222 /$

Sims, D. (2011). Understanding Cairo: The logic of a city out of control. Cairo: America University Press in Cairo. https://doi.org/10.5743/cairo/9789774164040.001.0001

Sims, D. (2015). Egypt's desert dreams: development or disaster? Cairo: American University Press in Cairo. https://doi.org/10.5743/cairo/9789774166686.001.0001

Soliman, A. (2012a, October). Tilting at pyramids: informality of land conversion in Cairo. In Sixth Urban Research and Knowledge Symposium (pp. 336-387). Rethinking Cities: Framing the Future, Barcelona, Spain: World Bank.

Soliman, A. M. (2012b). The Egyptian episode of selfbuild housing. Habitat International, 36(2), 226-236. https://doi.org/10.1016/j.habitatint.2011.08.004

Soliman, A. (2004). A Possible Way Out: Formalizing Housing Informality in Egyptian Cities. Lanham: American University Press.

Soliman, A. (2021). Urban Informality: Experiences and Urban Sustainability Transitions in Middle East Cities. Cham, Switzerland: Springer Nature. https://doi.org/10.1007/978-3-030-68988-9

Suzuki, H., Murakami, J., Hong, Y. H., \& Tamayose, B. (2015). Financing Transit-Oriented Development with Land Values: Adapting Land Value Capture in Developing Countries. Washington: International Bank for Reconstruction and Development. https://doi.org/10.1596/978-1-4648-0149-5

UN-Habitat. (2021). Egypt Human Development Report. The United Nations Development Programme, Ministry of Planning and Economic Development, Egypt: UNHabitat. https://sustainabledevelopment.un.org/content/documen ts/279512021_VNR_Report_Egypt.pdf 